\title{
Postfire tree mortality and fire resistance patterns in pine forests of Ukraine
}

\author{
Serhii Sydorenko ${ }^{1 *}$, Volodymyr Voron ${ }^{1}$, Iryna Koval ${ }^{1}$, Svitlana Sydorenko ${ }^{1}$, \\ Maksym Rumiantsev ${ }^{1}$, Roman Hurzhii ${ }^{2}$ \\ ${ }^{1}$ Ukrainian Research Institute of Forestry and Forest Melioration named after G. M. Vysotsky, \\ 86 Pushkinska Str., 61024, Kharkiv, Ukraine \\ ${ }^{2}$ Department of Forestry, National University of Life and Environmental Sciences of Ukraine, \\ 15 Heroiv Oborony Str., 03041, Kyiv, Ukraine
}

\begin{abstract}
The study was conducted in pure Scots pine (Pinus sylvestris L.) stands within the forest steppe physiographic region of Ukraine damaged by surface fires with different intensity. The aim of the research is to determine the effect of different fire intensity on pine stand and individual trees, considering tree morphometric parameters and type of damage. The intensity and duration of fire-related tree mortality was different in stands with different age. We found that tree fire resistance is driven by tree diameter, height of the rough bark, and natural degree of thickness. The proportion of dead trees one year after the spring fires in the middle-aged pine stands was 5 times lower and in mature pine stands even 10 times lower than after the summer fires. The critical damage to tree crowns in young pine trees causing their death is $80 \%$ of the needles burned. In the middle-aged pine trees, critical damage depended on the size of trees. The death of large, mature trees after smoldering summer fires was associated with the accumulation of a large stock of forest litter and duff near the tree-base, which contributed to the increased intensity of fire and its localization near the base part of the trees. Based on our findings, postfire tree mortality models have been developed for different age groups of pine stands.
\end{abstract}

Key words: surface fires; smoldering fires; postfire mortality models; bark char; crown scorch; season of fire

Editor: Tomáš Hlásny

\section{Introduction}

Wildfires are one of the most dangerous factors for forests, leading to their destruction and degradation. Due to global warming and increasing aridity, the risk of increased frequency and extent of wildfires is very high. Many regions of the world have experienced an increasing trend of excessive wildfires and an increasing occurrence of extremely severe fires (FAO 2006).

In 2017, wildfires burnt over 1.2 million hectares of natural lands in the EU. The European Forest Fire Information System estimated the amount of fire-related losses to be around 10 billion Euros (San-Miguel-Ayanz et al. 2017).

In Europe, Scots pine forests now exceed 28 million hectares, covering over $20 \%$ of the productive forest area (Mason \& Alì 2000). The most fire hazardous coniferous forests occupy $43 \%$ of the total area of Ukraine, in particular, pine stands $-35 \%$, which grow in the North of Ukraine (Polissya) and in the South (Steppe) along the largest rivers, also in the Crimea Peninsula. More than $90 \%$ of forest fires in Ukraine occur in pine forests (Voron \& Melnyk 2009; Voron \& Sydorenko 2014). During the last ten years (2009-2018), 19.9 thousand forest fires have occurred in Ukraine on an area of 37.2 hectares. The economic losses amounted to 8.86 million Euros (Public Report 2017).

The rapid deterioration of the sanitary state of damaged trees leads to significant economic losses due to the decline of stand merchantability and the deterioration of its technical quality. Timely diagnosis and accurate prediction of the postfire trees mortality are thus extremely important. Such studies can mitigate the negative effects of wildfires and will be used to support decisions about forestry treatments in such forests. A considerable amount of research papers is devoted to the prediction of postfire loss of trees for different conifer species (Regelbrugge \& Conard 1993; Usenya \& Churylo 2001; Fites-Kaufman et al. 2008; Sah et al. 2019). It is well known that the value of postfire mortality rate affects 
the predominant type of damage and fire intensity as well as secondary disturbances such as drought, insects, and diseases (Ahafonov \& Alekseev 1989). The research on the impact of fire damage on postfire tree mortality in Ukraine is rather fragmented. The existing diagnostics and predictions of postfire sanitary condition of damaged trees is based on an assessment of the state of tree crowns and visible damages without considering the main factors controlling the fire resistance of trees.

The main goal of this study is to find additional criteria that reflect the intensity of damage and the morphological indicators of fire resistance of pine trees for the development of postfire tree mortality models.

\section{Materials and methods}

The study was conducted in the pine forests of the forest steppe of Ukraine. The climate is mild, moderately continental. The total precipitation is $546 \mathrm{~mm}_{\text {peryear }}{ }^{-1}$, of which $38-40 \%$ falls during the growing season. The duration of the growing season lasts 205 days. The period with an average daily temperature of $+5^{\circ} \mathrm{C}$ to $+15^{\circ} \mathrm{C}$ is 80-90 days. Climatic stress factors (high temperatures in the summer months with the absence of rainfalls, irregular rainfall, long dry periods, evaporation exceeding precipitation) cause repeated occurrence of forest fires.

Study plots (SP) were established in pine stands homogeneous by forest type conditions and stand composition.

The evaluation of fire damage to the tree trunks was determined by the following indicators:

- the bark char height (minimum and maximum), m;

- fire damage of thin (light) bark;

- relative bark char, \%;

Relative bark char was determined by the formula [1]:

$$
H_{\text {rel }}=\left(H_{m \text { char }} / H\right) \times 100 \%
$$

where $H_{\text {rel }}$ - relative bark char, \%; $H$ - height of tree, $\mathrm{m} ; H_{m \text { char }}$ - the maximum height of the bark char, $m$.

The evaluation of the crown damage was based on the following:

- discoloration, \% (the proportion of needles that have lost their natural color, with an accuracy of $10 \%$, no later than a week after the fire damage) (Eichhorn et al. 2010);

- defoliation, \% (accuracy up to 10\%).

The following tree characteristics were determined: tree height, m; DBH, cm; class of Kraft; height of rough bark, m; number of first-order roots above ground. Natural degrees of thickness (NDT) were additionally calculated for each plantation on the test plots. The date of fire, the date of measurement, the soil condition and the stand age were recorded. We also examined a one-year postfire period, when the intensity of postfire tree mortality was the most intensive.

The sanitary state of the pine stand was characterized by the index of sanitary condition, which was determined by the formula [2] (Sanitary Forests Regulations in Ukraine, 2016):

$$
I_{c}=K_{1} \times n_{1}+K_{2} \times n_{2}+K_{3} \times n_{3}+\ldots K_{6} \times n_{6} / N
$$

where: $I_{c}$-index of sanitary state; $K_{1} \ldots K_{6}$-category of sanitary state for individual tree (from I to VI); $n_{1} . . . n_{6}-$ number of trees with specific sanitary category, stems; $N$-total number of trees on a study plot.

The sanitary state of each tree was determined according to 6 categories (Table 1 ).

The degree of differentiation of trees in the stand was evaluated according to the Kraft classification (Pogrebnyak 1968):

I - predominant, exceptionally large trees, which dominate the others, have the highest height and diameter and well-developed crowns;

II - dominant trees, which have relatively well-developed crowns and about the same height as class I trees;

III - low co-dominant trees, normally developed, smaller in height than the trees of the previous classes, with less developed, compressed crowns;

IV - dominated trees whose crowns are compressed and the tops reach only the lower part of the crown of the dominant trees;

$\mathrm{V}$ - entirely overtopped trees completely under the canopy of dominant trees, far behind in growth and development.

The postfire growth of the damaged trees was investigated on 33 study plots (3 SP in young pine stands, 21 SP in middle-aged and premature stands, and 10 SP in mature and overmature stands). The stands on the SP differed in age and forestry characteristics (Table 2).

Stand structure was characterized by a curve of trees distribution by natural degrees of thickness (NDT). Natural degrees of thickness are an indicator of the tree size by diameter (DBH), expressed in relative proportion of the average diameter of the stand. (Tyurin 1945; Mashkovsky 2015).

\begin{tabular}{|c|c|c|c|c|}
\hline \multirow{2}{*}{ Range of the sanitary index } & \multicolumn{2}{|r|}{ Needle packing } & \multirow{2}{*}{ Needles color } & \multirow{2}{*}{ The degree of stand damage } \\
\hline & [\%] & distribution of needles on shoots & & \\
\hline $1.00-1.50$ & $90-100$ & without signs of violation & green & absent \\
\hline $1.51-2.50$ & $66-90$ & without signs of violation & green, light green & weak \\
\hline $2.51-3.50$ & $33-66$ & clustered & pale green & medium \\
\hline $3.51-4.50$ & 33 & clustered & with a yellow tint or yellow-green & strong \\
\hline $4.51-6.00$ & 0 & there are no living needles & gray, yellow & very strong \\
\hline $4.51-6.00$ & 0 & there are no living needles & - & very strong \\
\hline
\end{tabular}

Table 1. Criteria for determining the sanitary index of pine stands. 
Table 2. Characteristics of study plots damaged by surface fires.

\begin{tabular}{|c|c|c|c|c|c|c|}
\hline No SP & $H_{\text {char }}[\mathrm{m}]$ & $A$ [years] & $D[\mathrm{~cm}]$ & $H[\mathrm{~m}]$ & $\begin{array}{c}M \\
{\left[\mathrm{~m}^{3} \mathrm{ha}^{-1}\right]}\end{array}$ & Relative density \\
\hline \multicolumn{7}{|c|}{ Yong pine stands } \\
\hline \multicolumn{7}{|c|}{ Summer fires or spring fires } \\
\hline 1 & 1.20 & 11 & 5.3 & 3.8 & 9 & 0.90 \\
\hline 2 & 0.90 & 11 & 7.3 & 4.1 & 9 & 0.90 \\
\hline Control & - & 11 & 5.5 & 4.0 & 9 & 0.90 \\
\hline \multicolumn{7}{|c|}{ Middle aged stands } \\
\hline \multicolumn{7}{|c|}{ Summer fires } \\
\hline 1 & 0.69 & 60 & 27.2 & 24.5 & 386 & 0.77 \\
\hline 2 & 2.02 & 57 & 26.0 & 21.0 & 476 & 1.00 \\
\hline 3 & 2.30 & 57 & 21.1 & 18.7 & 238 & 0.58 \\
\hline 4 & 2.52 & 60 & 28.4 & 25.2 & 481 & 0.93 \\
\hline 5 & 3.58 & 68 & 25.3 & 20.8 & 256 & 0.62 \\
\hline 6 & 4.45 & 70 & 26.5 & 21.2 & 261 & 0.62 \\
\hline 7 & 0.78 & 61 & 28.6 & 25.7 & 268 & 0.50 \\
\hline 8 & 1.26 & 61 & 21.8 & 19.6 & 220 & 0.60 \\
\hline 9 & 1.85 & 65 & 28.4 & 22.2 & 375 & 0.91 \\
\hline 10 & 1.98 & 65 & 26.6 & 22.5 & 401 & 0.96 \\
\hline 11 & 0.95 & 65 & 25.3 & 23.1 & 419 & 0.94 \\
\hline \multicolumn{7}{|c|}{ Spring fires } \\
\hline 12 & 2.05 & 60 & 25.8 & 22.9 & 384 & 0.82 \\
\hline 13 & 2.22 & 60 & 29.5 & 23.5 & 466 & 0.97 \\
\hline 14 & 3.06 & 47 & 24.0 & 21.8 & 327 & 0.74 \\
\hline 15 & 0.20 & 66 & 26.3 & 23.2 & 411 & 0.86 \\
\hline 16 & 0.30 & 59 & 27.7 & 22.4 & 442 & 0.96 \\
\hline 17 & 0.30 & 60 & 29.5 & 23.1 & 419 & 0.88 \\
\hline 18 & 0.80 & 60 & 25.8 & 22.9 & 380 & 0.80 \\
\hline 19 & 2.97 & 60 & 22.6 & 21.0 & 389 & 0.91 \\
\hline 20 & 2.90 & 55 & 17.1 & 18.5 & 185 & 0.88 \\
\hline \multicolumn{7}{|c|}{ Mature and overmature } \\
\hline \multicolumn{7}{|c|}{ Spring fires } \\
\hline 21 & 1.10 & 81 & 31.2 & 23.0 & 370 & 0.70 \\
\hline 22 & 3.00 & 81 & 37.3 & 26.2 & 390 & 0.60 \\
\hline 23 & 2.33 & 88 & 30.1 & 27.3 & 642 & 0.99 \\
\hline 24 & 2.46 & 88 & 31.2 & 24.8 & 480 & 0.93 \\
\hline 25 & 1.81 & 86 & 34.7 & 26.0 & 375 & 0.69 \\
\hline 26 & 2.40 & 86 & 33.2 & 26.6 & 476 & 0.96 \\
\hline 27 & 1.90 & 86 & 31.1 & 25.2 & 398 & 0.77 \\
\hline \multicolumn{7}{|c|}{ Summer fires } \\
\hline 28 & 0.48 & 95 & 42.6 & 27.2 & 361 & 0.60 \\
\hline 29 & 2.02 & 116 & 50.4 & 31.1 & 477 & 0.72 \\
\hline 30 & 2.16 & 116 & 42.6 & 29.8 & 385 & 0.60 \\
\hline
\end{tabular}

Classification of pine stands by age group was performed according to the following criteria (Svyrydenko et al. 2004):

- young (pine stands up to 40 years old);

- middle-aged (41 to 80 years old);

- premature stands (from 81 to 90 years);

- mature and overmature (over 90 years old).

Tree resistance was assessed using Pearson's correlation. Correlation analysis was used to assess possible linear associations between tree sanitary index and potential variables that reflect fire resistance: $\mathrm{DBH}$ (diameter at breast height), NDT, tree height, tree age, bark thickness, rough bark height, etc.

Multiple regression analysis as well as logistic regression analysis (binary regression) were used to construct predictive models for the tree mortality probability of individual trees. The use of logistic regression is appropriate to determine the likelihood of individual trees mortality. Logistic regression quality and accuracy were tested by ROC analysis using IBM's SPSS 20. For the analysis of model quality and its cut-off threshold correction ROC-analysis (receiver operating characteristic) was used. In ROC-analysis, model quality is considered to be excellent at AUC (area under curve) value 0.9-1.0; very good at $0.8-0.9$; good at $0.7-0.8$; average at $0.6-0.7$; poor at $0.5-0.6$ (Fawcett 2004).

While studying the influence of Kraft class (KC) on the resistance to fire damage of trees with the same height of bark char, a sampling of trees was selected from the whole set of trees within the range of bark char height 0.51-1.00 m differing in KC. Despite a small number of I-II and IV-V KC trees, they were joined into groups: I-II, III and IV-V KC. One-way ANOVA was used. The power of the influence of the factor was determined by the method of Plokhinsky (Lakyn 1990).

\section{Results}

\subsection{Postfire tree mortality in the young pine stands}

A significant correlation $(r=0.92 ; p=0.05)$ was found between the level of discoloration and the sanitary condition of the trees. The highest intensity of mortality was determined in the year of the fire, when $23.8 \%$ of the total number of trees. In the following year, the mortality rate decreased, reaching $5.6 \%$ of trees, and $1.7 \%$ of trees in the third year after the fire.

It has been found that the lethal level of damage to young pine trees is achieved when the relative bark char $\left(H_{\text {rel. }}\right)$ reaches $61-70 \%$. In this case, mortality reaches $82 \%$ of trees, corresponding with the $80 \%$ of the growing stock (Table 3).

Small damages of tree crowns (up to $30 \%$ ) did not lead to tree mortality. Significant deterioration of the sanitary state with the subsequent death of a significant number of trees was observed in the case of a severe damage to the crown - more than $81 \%$. Trees with over $91 \%$ damage to the crown died within a year after the fire.

Table 3. Distribution of dead trees depending on the type and value level of damage in the pine young stands of Vasyshchevske Forestry, State Enterprise Zhovtneve, Kharkiv region.

\begin{tabular}{|c|c|c|c|c|}
\hline \multirow{3}{*}{$\begin{array}{c}\text { The value of damage } \\
{[\%]}\end{array}$} & \multicolumn{4}{|c|}{ Proportion of dead trees [\%] } \\
\hline & \multicolumn{2}{|c|}{$\mathrm{H}_{\text {rel. }}[\%]$} & \multicolumn{2}{|c|}{$\mathrm{D}[\%]$} \\
\hline & $\mathrm{N}$ & $\mathrm{M}$ & $\mathrm{N}$ & $\mathrm{M}$ \\
\hline$\overline{0-10}$ & 6 & 1 & - & - \\
\hline $11-20$ & 7 & 1 & - & - \\
\hline $21-30$ & 8 & 1 & - & - \\
\hline $31-40$ & 25 & 20 & - & - \\
\hline $41-50$ & 35 & 32 & - & - \\
\hline $51-60$ & 71 & 75 & - & - \\
\hline $61-70$ & 82 & 80 & 3 & 1 \\
\hline $71-80$ & - & - & 4 & 1 \\
\hline $81-90$ & - & - & 38 & 42 \\
\hline $91-100$ & 94 & 92 & 94 & 96 \\
\hline
\end{tabular}

Note: $H_{\text {rel }}$ - relative bark char, \%; $D$ - crown discoloration, $\% ; N$ - number of trees, stems, \%; $M$ - percent of the stock, \%.

Larger pine trees were more fire resistant. Characteristics such as diameter, height and class of Kraft were the best indicators of fire resistance in young pine stands. 
It has been confirmed that a model that considers tree diameter, relative bark char, and crown discoloration (AUC $=0.95 \pm 0.012$ ) performs best in predicting the probability of tree mortality.

A simplified version of model, which included only the magnitude of crown discoloration, had an AUC value of $0.93 \pm 0.014$. Both models have "excellent" quality in classification (Fawcett 2004), so we suggest to use the simplified model (3) that includes discoloration and predicts postfire mortality with an accuracy of $89.9 \%$. This model correctly predicts the postfire status of surviving trees with an accuracy of up to $94.3 \%$ and of dead trees up to $80 \%$. The risk of trees mortality is extremely high with a discoloration of over $80 \%$.

$$
P=\frac{\exp (-9.095+0.111 \times D)}{\left(1+\exp (-9.095+0.111 \times D)^{\prime}\right.}
$$

where $P$ is the probability of postfire mortality; $D$ - crown discoloration,\%.

\subsection{Postfire tree mortality in the middle-aged pine stands}

Middle aged middle-aged pine trees were found to be characterized by an increase in fire resistance of trees with an increase in trunk diameter (a correlation between the diameter and the sanitary condition of damaged trees was revealed: $r=-0.4 ; p=0.05$ ).

Stands with the same level of damage caused during fires that occurred in different seasons of the year were exhibiting different intensity of mortality. We found that mortality rate after summer fires can be 10 times higher than after spring fires. Trees with the same value of damage (mean height of bark char) and age but damaged in different seasons had a different reaction to fire damage. The index of sanitary state after spring fires was 2.48; after summer fires -4.4 (ANOVA results: $\mathrm{F}_{\mathrm{f}}=79.8$ and $\left.\mathrm{F}_{0.001}=12.4, \mathrm{~h}^{2}=0.77\right)$.

After spring fires, the index of sanitary state, even with significant damage to the trunk (bark char height above $4 \mathrm{~m}$ ), ranged from 2.6 to 2.8 (weakened stand). After the spring surface fires, only Kraft class IV-V trees died out. The percentage of dead trees increased in stands with a larger proportion of IV and V Class Kraft (CK) trees. Thus, in damaged pine trees, the fire accelerated the natural liquefaction of the stands. The significance of the influence of the investigated factor was proved by comparing trees that are homogeneous in their level of damage and taxation characteristics but different in Kraft classes $\left(\mathrm{F}_{\mathrm{f}}=6.47 ; \mathrm{F}_{0.05}=4.88\right)$.

A strong direct relationship between the bark char on the tree trunks and the sanitary state of the trees was established $\left(\mathrm{r}=0.91, \mathrm{t}_{\mathrm{f}}=6.80, \mathrm{t}_{0.01}=3.17\right)$. The results of the regression analysis show that in $83 \%$ of cases after summer fires, the sanitary state of trees is determined by the average bark char on trees. It was also proved the proportion of dead trees after the fire in the studied tree groups increases in response to the increasing average height of the bark char $\left(\mathrm{r}=0.87, \mathrm{t}_{\mathrm{f}}=5.80, \mathrm{t}_{0.01}=3.17\right)$ (Fig. 1).

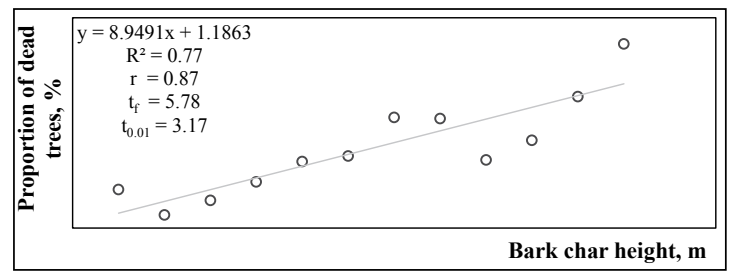

Fig. 1. Relationship between the proportion of dead trees and average bark char height on the trunks in middle-aged pine stands damaged by surface fires in summer.

The postfire models were further improved by considering the distribution of trees by NDT (ranking trees in the planting relative to the average diameter) that contains both the class of tree development (Kraft class) in the stand and its size (diameter). A negative correlation $(\mathrm{r}=-0.54 ; \mathrm{p}=0.05)$ was found between the sanitary state and the NDT; a less close relationship was found between the diameters and the sanitary condition of the trees $(r=0.40 ; p=0,05)$.

For NDT 0.7-1.2, lethal damage occurs at the height of up to $3 \mathrm{~m}$ on the trunk (the index of sanitary state reaching 4.1-4.6). For trees with NDT more than 1.3, lethal damage is achieved only if the height of bark char exceeds $4 \mathrm{~m}$ (Table 4).

Table 4. Proportion of dead trees depending on the natural degrees of thickness and average bark char height after summer surface fires.

\begin{tabular}{lcccccc}
\hline$H_{\text {char }}[\mathrm{m}]$ & \multicolumn{7}{c}{$\mathrm{NDT}$} \\
\cline { 2 - 7 } & $>0.6$ & $0.7-0.8$ & $0.9-1.0$ & $1.1-1.2$ & $1.3-1.4$ & $1.5>$ \\
\hline$>1.0$ & 22 & 11 & 8 & 1 & 0 & 0 \\
$1.1-2.0$ & 47 & 12 & 10 & 1 & 0 & 0 \\
$2.1-3.0$ & 71 & 30 & 34 & 3 & 9 & - \\
$3.1-4.0$ & 75 & 42 & 41 & 29 & 0 & - \\
$4.1>$ & - & 100 & 43 & 36 & 40 & 33 \\
\hline
\end{tabular}

Note: $H_{\text {char }}-\mathrm{m}$; NDT - natural degree of thickness.

An increase in the proportion of dead trees with the increasing average height of bark char was detected in the groups of trees that were different in NDT and the average height of bark char. The group of trees depressed in growth (NDT 0.5-0.7) is characterized by an extremely high proportion of dead trees, which increases rapidly (from 22 to $75 \%$ ) with the growth of damage intensity. For trees with the NDT of $0.7-1.0$, the critical bark char height is more than $2 \mathrm{~m}$ (the share of dead trees comprises 30-34\%).

The best performing models based on the logistic regression analysis included the natural degree of thickness and the average bark char height $\left(\mathrm{H}_{\text {char }}\right)$ (Fig. 2) (4). 


$$
P=\frac{\exp \left(2.67-5.20 \times N D T+0.61 \times H_{c e p}\right)}{\left(1-\exp \left(2.67-5.20 \times N D T+0.61 \times H_{c e p}\right)\right)^{\prime}}
$$

where $P$ stands for the probability of postfire tree mortality (from 0 to 1 ); $N D T$ is the natural degree of thickness; $H_{\text {char }}$ is the average bark char height on the tree trunks.

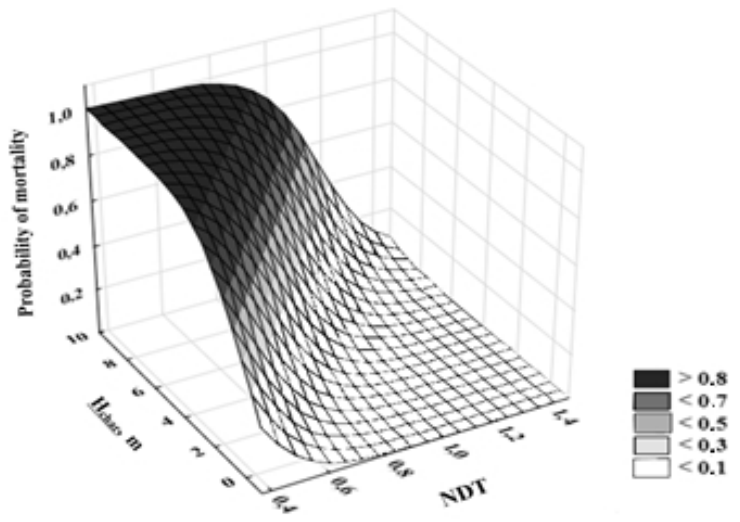

Fig. 2. Probability of postfire mortality in middle-aged pine stands depending on the height of bark char and the natural degree of thickness (NDT). The accuracy of the prediction model reaches $78.2 \%$. The high quality of the proposed model was confirmed by ROC analysis (AUC $=0.83 \pm 0.020$ ). The inclusion of more variables in the model did not increase its accuracy by more than $1 \%$. According to the sanitary condition classification, the dead trees belonged to the fifth and sixth categories of the sanitary condition. "The dying trees" susceptible to stem tree beetles (category IV of sanitary state) that will probably die with time have not been taken into account, so the cut-off limit for the above model has been reduced to 0.38 .

The one-way ANOVA analysis confirmed the significance of fire damage of thin (light) bark. Trees with average NDT ranging from 0.9 to 1.1 , same age and in bark char height on the trunks $(2.8-3.1 \mathrm{~m})$, were selected for analysis. The sample was divided into three groups: "rough bark" - when the bark char did not exceed the height of the rough bark; "transition zone" - when the bark char reached one meter below the zone of transition to thin bark or reached the zone of transition of the coarse bark; and the third group, "thin (light) bark damage" the height of bark char exceeded the zone of transition of the rough bark to the thin one. The effect of thin bark area damage on the trees' sanitary state was statistically significant $(\mathrm{Ff}=5.98 ; \mathrm{Fst}=3.07 ;(\mathrm{p}=0.003)($ Fig. 3, Fig. 4).

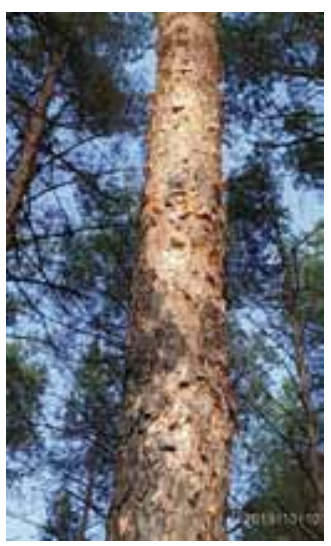

Thus, selecting dryingprone trees for cutting (as trees that are likely to die), it is worth paying attention to the presence of thin bark burns. In cases where the height of the bark char height exceeds the height of the coarse bark (thin bark fire damage), the likelihood of postfire trees mortality increases dramatically.

Fig. 3. Transition zone: rough bark goes into thin light color bark.

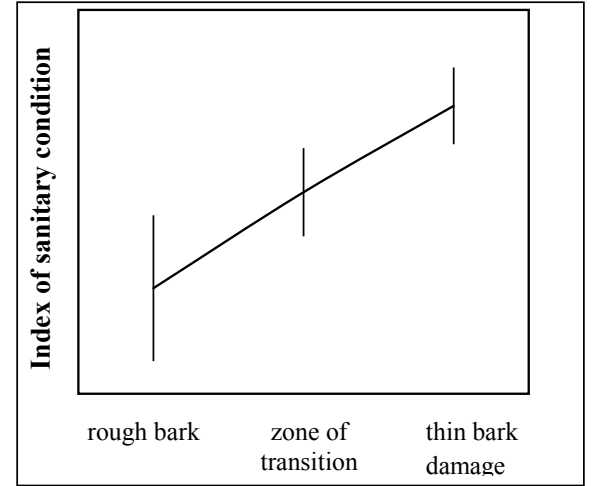

Fig. 4. Index of sanitary condition for groups of trees which have equal height of bark char.

\subsection{Postfire tree mortality in the mature pine stands}

It was found that in mature pine stands there is no significant relationship between bark char height and the trees' sanitary state. Taking into account the role of the char height on the trunks as an indicator of fire damage, tables of predicted mortality were drawn up separately for summer and spring fires (Table 5).

Table 5. Sanitary state and postfire mortality in mature pine stands damaged by surface fires.

\begin{tabular}{|c|c|c|c|c|c|c|}
\hline \multirow{4}{*}{$\begin{array}{l}H_{\text {char }} \\
{[\mathrm{m}]}\end{array}$} & \multicolumn{6}{|c|}{ Season of fire } \\
\hline & \multicolumn{4}{|c|}{ Spring } & \multicolumn{2}{|c|}{ Summer } \\
\hline & \multirow[b]{2}{*}{$\mathrm{I}_{\mathrm{s}}$} & \multicolumn{2}{|c|}{ Proportion of dead trees [\%] } & \multirow[b]{2}{*}{$I_{s}$} & \multicolumn{2}{|c|}{ Proportion of dead trees [\%] } \\
\hline & & $\mathrm{N}$ & $\mathrm{M}$ & & $\mathrm{N}$ & $\bar{M}$ \\
\hline $0-0.5$ & 2.7 & 5.9 & 2.6 & 4.3 & 33.0 & 38.4 \\
\hline $0.5-1.0$ & 3.0 & 7.4 & 3.2 & 4.5 & 54.0 & 55.9 \\
\hline $1.1-1.5$ & 2.9 & 5.4 & 1.7 & 4.1 & 56.0 & 65.6 \\
\hline $1.5-2.0$ & 2.9 & 5.4 & 3.5 & 4.3 & 31.0 & 27.0 \\
\hline $2.1-2.5$ & 2.9 & 1.5 & 1.2 & 4.7 & 64.0 & 52.3 \\
\hline $2.6-3.0$ & 2.9 & 4.8 & 3.4 & 4.7 & 64.0 & 72.1 \\
\hline $3.1-4.0$ & 2.7 & 3.0 & 4.2 & 5.7 & 83.0 & 72.3 \\
\hline
\end{tabular}
share of the stock, $\%$

It was found that the damage caused by the spring fires did not pose a threat - the proportion of dead trees in the total stand stock did not exceed $3.4 \%$. This indicates that the least developed trees die after the spring fires.

After the summer fires, the trees affected by any damage responded with rapid deterioration of their sanitary state. No significant relationship was found between the sanitary state of trees and damage value, although there is a tendency toward an increase in the proportion of dead trees as the average height of bark char increases (from 31 to $83 \%$ by the number of trees and from 27 to $72.3 \%$ by the stock). The proportion of dead trees by the number was inferior to the share of dead trees by the stock. This indicates that after the summer surface fires, the most developed dominant and predominant trees have a higher probability of mortality.

The suppressed small trees in the pine stand died at any level of damage (natural thinning by suppression) (Table 6). At the same time, the most developed trees 
of the highest natural degree of thickness (NDT) also responded to the damage most radically - the mortality rate was $48-55 \%$ even with minimal damage (the height of bark char up to one meter) and $100 \%$ for the bark char above one meter.

Trees whose DBH was inferior to the average in the stand, namely with a natural degree of thickness $0.7-0.8$, were found to be the most fire resistant. The mortality rate in this group is minimal $(0-5 \%)$. Thus, the diameter of mature and overmature pine trees is not an indicator of fire resistance: the slightly less developed and thinner trees have proved more resistant.

Table 6. Proportion of dead trees in mature pine stands, depending on the natural degrees of thickness (NDT) and bark char height $\left(H_{\text {char }}\right)$ after summer smoldering fires, \%.

\begin{tabular}{lccccc}
\hline \multicolumn{2}{c}{ Bark char height $\left(H_{\text {char }}\right)$} & \multicolumn{5}{c}{ Natural degrees of thickness } \\
\cline { 2 - 6 } & $>0.6$ & $0.7-0.8$ & $0.9-1.0$ & $1.1-1.2$ & $1.3-1.4$ \\
\hline$>1.0$ & 43 & 5 & 48 & 54 & 55 \\
$1.1-2.0$ & - & 0 & 69 & 100 & 100 \\
$2.1-3.0$ & - & 0 & 100 & 100 & 100 \\
$3.1-4.0$ & - & 0 & 100 & 100 & 100 \\
\hline
\end{tabular}

A tendency was established toward an increase in the share of dead trees with an increase in their diameter. Correlation analysis established a strong direct reliable relationship $\left(\mathrm{t}_{\mathrm{f}}=5.84 ; \mathrm{t}_{0.01}=3.71\right)$ between these indicators. One of the reasons for the higher mortality of largesized trees was the bigger amount of litter accumulated near tree basis. Thus, in the undamaged parts of the pine stands measurements were taken of the thickness of the litter and duff at different distances from the trunk.

The thickness of litter and duff layers near the tree basis varied within 7 to $14 \mathrm{~cm}$ (average value $-11.0 \pm$ $0.52 \mathrm{~cm}$ ) and decreased as the distance from the trunk increased to $2.6 \pm 0.30 \mathrm{~cm}$, which is statistically confirmed $\left(\mathrm{F}_{\mathrm{f}}=56,8 ; \mathrm{F}_{0,001}=2.7\right)$. Rough bark reaches only the level of the litter, therefore surface fires severely damage the cambium, leading to the weakening of the tree and ultimately to dying. It was found that the thickness of the bark on the pine root paws can be 2.5 times smaller than on the trunk above $-8.8 \pm 0.99$ mm versus $22.2 \pm$ $2.29 \mathrm{~mm}$. The reliability of the difference in bark thickness on model trees was statistically confirmed $\left(\mathrm{t}_{\mathrm{f}}=5.54\right.$; $t_{0.05}=2.26$ ). The presence of open root paws, on the one hand, indicates damage to the first order roots, while on the other, is an indicator of a strong degree of forest litter combustion, which causes also damage to fine roots.

\section{Discussion}

Our results show that the response of pine trees of different age groups to the effect of surface fire differs greatly. In young pine stands, damage to the crown with simultaneous damage to the tree trunk prevails. In middle-aged pine trees prevails damage to the trunk; in mature pine stands - damage to the trunk by heat radiation and root systems (roots of the first order at the base of the tree). The deterioration of tree sanitary state or even the death of trees after the surface fire is caused by damage to stem tissues; buds and needles in the crown of the tree; damage to tree roots (Valendik et al. 2006; Kosov 2008), but the authors do not provide critical levels of damage for each age group of pine stands. The bark char indicator is widely used alone or in combination with crown scorch to predict postfire mortality of pine forests. These two indicators are considered to be the most significant ones (De Bano \& Conrad 1978; McHugh \& Kolb 2003). Kobechinskaya and Oturina (1997) indicated that the height of bark char is not necessarily the main criterion for the mortality in a stand. According to their research in the Crimea, the proportion of dead pine trees varies greatly, with the same height and different combustion and destruction of cambium. In our opinion, such variation is caused by differences in the stand and individual trees characteristics.

According to Dieterich (1979), the amount of damage to the crowns during fires has been identified as the main cause of coniferous tree mortality and has been successfully used to predict postfire mortality. In our opinion, crown scorch should be included in the prediction models of postfire tree mortality, especially for predicting mortality in young pine stands, where this type of damage is typical during surface fires and closely correlates with the deterioration of the sanitary state of damaged trees. The surface fires in the young pine stands are extremely dangerous. Because of the low height crown attachment, the fire causes severe damage to both tree trunks and tree crowns. Due to this, for young pine stands it is advisable to use also "relative bark char" (the ratio of maximum bark char height to the height of the tree) as an additional indicator. This criterion is not new and was used Regelbrugge and Conard (1993), but it is appropriate to use it for young pine stands. This technique allows to predict postfire mortality of trees more accurately, compared to using the "char height" indicator. According to our results, the lethal damage value of the crown scorch for young pine trees is $80 \%$ and relative bark char $-60 \%$.

Critical for pine stands damaged during summer fires can be considered the average height of bark char above two meters, the sanitary index being 3.4 and the proportion of dead trees reaching $21 \%$. As the average bark char height increased, so did the proportion of dead trees from $21 \%$ for bark char height of $1.5-2 \mathrm{~m}$ to $70 \%$ for bark char of more than $5 \mathrm{~m}$ the sanitary index ranging from 2.6 to 2.8 . The rate of postfire tree mortality was insignificant (1-6\%). The probability of postfire mortality of individual middle-aged trees after summer surface fires is determined depending on the diameter $(\mathrm{DBH})$ of the trees and the value of damage to the trunk. Trees of the lowest natural degree of thickness (NDT 0.6-0.7) are killed by minor damage to the trunk (up to $1 \mathrm{~m}$ ). The risk of postfire mortality for trees with the NDT of 1.0-1.1 is significant only when the height of bark char is more than $3.5 \mathrm{~m}$. 
As is evidenced in major research papers (De Bano \& Conrad 1978; Pinard \& Huffman 1997; Stephens \& Finney 2002), tree mortality rate is inversely related to the diameter of the trees, since larger trees typically have a thicker bark, which is a good insulator. According to our research, the height of the coarse bark may be an additional indicator of fire resistance of trees, especially for middle-age trees. The trees whose height of the bark char reaches the zone of the thin bark (its thickness being $0.1-0.9 \mathrm{~mm}$ ), respond to damage by deterioration of the sanitary state and have a higher probability of mortality.

The thermal insulation properties of the bark layer depend on its thickness, structure, bulk density and humidity. These bark characteristics vary widely across tree species. The bark of coniferous tree species from family Pinaceae (Pinus sylvestris L., Pinus pallasiana D. and others) is the most successfully adapted for the thermal isolation of living tissues from fire damage (Valendik et al. 2006). Some authors (Hare 1965) provide data about fire resistance, which is related to morphological features and increases with the size of the tree (diameter) and its age. Other authors have reported that the diameter and thickness of the bark are poorly correlated with the postfire mortality rate (Menges \& Deyrup 2001). Basically, the conclusions are often contradictory. On the other hand, authors of similar works (Hood et al. 2007) claim that trees with a larger diameter, on the contrary, are less resistant to fires. In our research, such conclusions are only partially confirmed. In mature pine trees, especially after the summer fires and smoldering fires, the fire resistance of the most developed trees was negligible, they died after exposure to even minimal fire damage. Tree mortality may take place in case of the small thickness of the bark and its high thermal conductivity in trees with smaller diameter (DBH) (Kosov et al. 2005), so young and middle-aged pine trees larger in size proved more fire-resistant and had a better sanitary state one year after fire. In our opinion, the authors came to different conclusions because they did not take into account the fire intensity, damage to the roots and tree morphological changes relative to its age. Our results have shown that the high rate of mortality and probability of mortality of more developed large trees in mature pine stands is associated with the accumulation of a relatively larger stock of litter and duff at the tree base near the trunks. This contributes to the increased intensity of fire and its localization near the tree trunk. The bark on the root paws $(8.8 \pm 0.99 \mathrm{~mm})$ in mature pines is 2.5 times thinner than on the trunk $10 \mathrm{~cm}$ above ground $(22.2 \pm$ $2.29 \mathrm{~mm}$ ). Therefore, summer surface fires damage the cambium in this location, which leads to the weakening of the trees and their subsequent dying. According to Fowler and Cieg (2004), damage to fine roots can be crucial for their postfire survival. Prolonged heat during smoldering fires can cause root damage when first order roots near the base of the trunk are damaged and die off. Along with them, the rest of the higher order roots, which are related to the first order roots, will also die (Guo et al. 2008). J. Varner (2009) demonstrates that the lethal temperature during a fire, spreads deeper than $20 \mathrm{~cm}$ into the soil. O'Brien found (O'Brien et al. 2010), that the fine roots of Pinus palustris Miller were almost evenly distributed in the lower layers of forest duff and developed in the upper $30 \mathrm{~cm}$ of soil. Although the thermal conductivity of the soil is negligible, the fire can, in certain conditions, significantly damage the root systems. Therefore, if the trees in the pine stand form a surface root system, a smoldering fire can significantly affect the root systems. At the same time, a steady smoldering fire that damaged the cambium near the root (tree basis zone) can cause a longterm weakening of the trees, reduce resistance to beetles' attacks and lead to the death of the pine stand. Similar processes were recorded byVarner (2009) in mature pine trees that were damaged during smoldering fire in the summer; such trees died even with slight damage (up to $0.5 \mathrm{~m}$ of bark char height). Varner, in his work, came to the same conclusion, finding that in low intensity surface fires, mature pine trees can withstand fire damage, but a smoldering fire in planting with a thick layer of litter and duff can cause more than $80 \%$ of trees to die (Thies et al. 2006; Varner et al. 2009).

The intensity of postfire mortality depends also on the season of fire (spring, summer, autumn). This phenomenon was not clear due to a number of reasons. For example, Menges and Deyrup (2001) argue that the intensity of post fire mortality is the highest after the autumn and winter fires. Harrington (1987) claimed that more intense postfire mortality occurred during spring fires (active season) than after autumn ones (dry season), while Thies (2005), on the other hand, determined greater tree mortality after fall than after spring. It is logical to assume that the season itself, as a factor, has little effect on tree mortality, the main role being played by the intensity and characteristic of the damage. That is, in the summer, the intensity of the fire is greater, especially during prolonged droughts when forest fuel dries up to a critical level. This hypothesis has been confirmed in the research of Thies (2006). Our results have shown that summer fires have a more negative impact on pine stands. Summer fires for middle-aged, mature and overmature pine stands have more significant consequences than spring fires. The intensity of postfire tree mortality after summer surface fires in mature pine trees was 10 times higher than after spring fires. Since spring fires are rapid, only the top thin layer of litter is burned during the fire, and the wetter ones do not burn out. Such type of damage is less significant than in summer, all the litter and duff burning, and damage to the trunk is also accompanied by damage to the root and the destruction of the most physiologically active fine roots in the topsoil. In addition, trees damaged in early spring do not experience lack of moisture, and they recover faster after being damaged. 


\section{Conclusions}

We conclude that fire resistance patterns in pine trees change during their growth and vary greatly between different age groups. We have found evidence that in young, middle-aged and premature pine stands the main indicators of fire resistance are connected to the tree size - large trees appear more resistant. The main indicators of fire resistance were thus tree diameter, tree height, NDT, Kraft class, and other related indicators. In mature stands, on the contrary, larger trees were less resistant to fire damage. The reason is that trees with larger diameter in mature pines stands accumulate a relatively larger stock of fuel (litter and duff) near the tree trunks. This contributes to the local increase of fire intensity and its localization near the tree trunk. Such local changes in fire behavior lead to severe damage to the lower part of tree trunks and the death of damaged trees. The height of the coarse bark may be an additional indicator of pine tree fire resistance. Trees whose height of the bark char does not exceed the zone of the coarse bark have a better sanitary condition and a higher probability of survival.

\section{References}

Ahafonov, A. F., Alekseev, Y. A., 1989: Drying of pure pine on fires. Forestry, 12:37-39.

De Bano, L. F., Conrad, C. E., 1978: The effect of fire on nutrients in a chaparral ecosystem. Ecology, 59:89-97.

Dieterich, J. H., 1979: Recovery potential of fire-damaged southwestern ponderosa pine. USDA Forest Service - Rocky Mountain Forest and Range Experiment Station Research Note RM-379. Ft. Collins, Colorado, $8 \mathrm{p}$.

Eichhorn, J., Roskams, P., Ferretti, M., Mues, V., Szepesi, A., Durrant, D., 2010: Visual assessment of crown condition and damaging agents. Manual Part IV. In: Manual on Methods and Criteria for Harmonized Sampling, Assessment, Monitoring and Analysis of the Effects of Air Pollution on Forests - UNECE-ICP Forests Programme Co-ordinating Centre, Hamburg, $49 \mathrm{p}$.

Fawcett, T., 2004: ROC Graphs: Notes and Practical Considerations for Researchers. Kluwer Academic Publishers, $38 \mathrm{p}$.

Fites-Kaufman, J. A., Weixelman, D., Merrill, A. G., 2008: One-Year Postfire Mortality of Large Trees in Low- and Moderate-Severity Portions of the Star Fire in the Sierra Nevada 1. Session K-Postfire Mortality of Large Trees in Sierra Nevada. USDA Forest Service General Technical Reports PSW-GTR-189:279-284.

Fowler, J. F., Sieg Fowler, C. H., 2004: Postfire mortality of ponderosa pine and Douglas-fir: a review of methods to predict tree death. Gen. Tech. Rep. RMRSGTR-132. USDA Forest Service, Fort Collins, Rocky Mountain Research Station, 25 p.
Guo, D. L., Mitchell, R. J., Withington, J. M., Fan, P. P., Hendricks, J. J., 2008: Endogenous and exogenous controls of root lifespan, mortality and nitrogen flux in a longleaf pine forest: root branch order predominates. Journal of Ecology, 96:737-745.

Hare, R. C., 1965: The contribution of bark to fire resistance of southern trees. Journal of Forestry, 4:248251.

Harrington, M. G., 1987: Ponderosa pine mortality from spring, summer, and fall crown scorching. Journal of Applied Forestry, 2:14-16.

Hood, S. M., Smith, S. L., Cluck, D. R., 2007: Delayed conifer tree mortality following fire in California. USDA Forest Service Gen. Tech. Rep. PSWGTR-203. USA, Albany, Calif., 261-283 p.

Kobechinskaya, V. G., Oturina, I. P., 1997: Ecological consequences of the impact of fires on the vegetation cover of mountain Crimea. Issues of bioindication and ecology of Zaporozhye, 2:28-31.

Kosov, I. V., 2008: The mechanism of the impact of grassroots fires on trees of coniferous species. Fires in Siberia's Forest Ecosystems - Vseros Materials. Conf. with international. participation, 17-19 September, 2008, Krasnoyarsk, p. 146-149.

Kosov, I. V., Kisilyahov, E. K., Rybnikov, V. Yu., 2005: The mechanism of damage to the stand during litterhumus fires. Nerd. researched in Siberia, Krasnoyarsk, 13:97-101.

Lakyn, H. F., 1990: Biometrics. 4th, rework. Moscow, Vyshcha shkola, $352 \mathrm{p}$.

Mashkovsky, V. P., 2015: Commoditization of the rated cutting by assortment tables with tree row distribution according to natural diameter classes. Problems of Forest and Forestry: collection of scientific works of Institute of Wood of NAS of Belarus, 75:340-348 p.

Mason, W. L., Alìa, R., 2000: Investigación agraria. Sistemas y recursos forestales, 9:3-17.

McHugh, C. W., Kolb, T. E., 2003: Ponderosa pine mortality following fire in northern Arizona. International Journal of Wildland Fire, 12:7-22.

Menges, E. S., Deyrup, M. A., 2001: Postfire survival in south Florida slash pine: interacting effects of fire intensity, fire season, vegetation, burn size, and bark beetles. International Journal of Wildland Fire, 10:53-63.

O’Brien, J. J., Hiers, J. K., Mitchell, R. J., Morgan Varner III, J., Mordecai, K., 2010: Acute physiological stress and mortality following fire in a long-unburned longleaf pine ecosystem. Fire Ecology, 6:1-12.

Pinard, M.A., Huffman, J., 1997: Fire resistance and bark properties of trees in a seasonally dry forest in eastern Bolivia. Journal of Tropical Ecology, 13:727-740.

Pogrebnyak, P. S., 1968: General forestry. Moscow, Kolos, $440 \mathrm{p}$.

Regelbrugge, J. C., Conard, S. G., 1993: Modeling tree mortality following wildfire in Pinus ponderosa forests in the central Sierra Nevada of California. International Journal of Wildland Fire, 3:139-148. 
Sah, J., Ross, M., Ogarcak, D., Snyder, J., 2006: Fuel Loads, Fire Severity, and Tree Mortality in Florida Keys Pine Forests. International Journal of Wildland Fire, 15:463-478.

San-Miguel-Ayanz, J., Durrant, T., Boca, R., Libertà, G., Branco, A., de Rigo, D., Ferrari, D.et al., 2017: Forest Fires in Europe, Middle East and North Africa, 142 p.

State Forest Resources Agency of Ukraine, 2017: Forests and forestry in Ukraine. Sci. Bull.UNFU, 27:10-15.

Stephens, S. L., Finney, M. A., 2002: Prescribed fire mortality of Sierra Nevada mixed conifer tree species: effects of crown damage and forest floor combustion. Ecology and Management, 162:261-271.

Svyrydenko, V.Ye., Babich, O. H., Kyrychok, L. S. 2004: Forestry. Textbook. Kyiv, Aristey, 544 p.

Thies, W. G., Westlind, D. J., Loewen, M., 2005: Season of prescribed burn in ponderosa pine forests in eastern Oregon: impact on pine mortality. International Journal of Wildland Fire, 14:223-231.

Thies, W. G., Westlind, D. J., Loewen, M., Brenner, G., 2006: Prediction of delayed mortality of fire-damaged ponderosa pine following prescribed fires in eastern Oregon, USA. International Journal of Wildland Fire, 15:19-29.
Tyurin, A. V., 1945: Forest mensuration. Moscow, Goslestekhizdat, $376 \mathrm{p}$.

Usenya, V. V., Churylo, V. S., 2001: The dynamics of post-fire mortality in pine stands. Problems of Forest and Forestry: collection of scientific works of Institute of Wood of NAS of Belarus, 52:209-214.

Valendik, E. N., Suhinin, A. I., Kosov, I. V. 2006: Effect of forest fires on the stability of conifers Krasnoyarsk. Krasnoyarsk, Scientific Center of the Siberian Branch of the RAS, $96 \mathrm{p}$.

Varner, J. M., Putz, F. E., O'Brien, J. J., Hiers, J. K., Mitchell, R. J., Gordon, D. R., 2009: Post-fire tree stress and growth following smoldering duff fires. Forest Ecology and Management, 258:2467-2474.

Voron, V. P., Melnyk, Ye. Ye., 2009: Tendencies of fires development in the forests of green belt of Kharkov. Forestry and Forest Melioration, 115:207-214.

\section{Internet sources:}

FAO, 2006: Fire management: Review of international cooperation. Fire Management Working Paper FM18E. Available at: https://www.fao.org/3/ j9406e/j9406e00.

Sanitary Forests Regulations in Ukraine, 2016:Approved by Cabinet of Ministers of Ukraine. Kyiv, 20 p. Available at: https://zakon.rada.gov.ua/laws/show/55595-\%D0\%BF\#Text. 